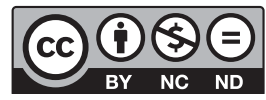

Estudos Teológicos foi licenciado com uma Licença Creative Commons Atribuição - NãoComercial - SemDerivados 3.0 Não Adaptada

http://dx.doi.org/10.22351/et.v58i2.3314

\title{
O debate sobre a teologia política em Merio Scattola ${ }^{1}$
}

\author{
Merio Scattola political theology's debate
}

Roberto E. Zwetsch ${ }^{2}$

Resenha de: SCATTOLA, Merio. Teologia politica. Trad. José Jacinto Correia Serra. Lisboa: Ed. 70, 2009. 268 p.

O livro é uma exposição histórica do tema/conceito "teologia política" desde os gregos até os dias de hoje. Compõe-se de cinco capítulos: I) História conceitual: teologia política e teologia civil; II) A fundação cristã do problema; III) A recapitulação quinhentista; IV) A idade Moderna e a nova forma de mediação política; V) O século XX. Epílogo e reabertura do problema teológico-político. Seguem a bibliografia e o índice onomástico. Aqui vou trazer brevemente as principais descobertas da leitura a partir da introdução e do cap. 5, para ir direto ao que nos interessa para o debate atual em torno do tema da teologia política.

$\mathrm{O}$ autor inicia afirmando três significados do conceito teologia política: 1) política da teologia; 2) teologia da política (significado filosófico-político); 3) teologia civil. Teologia começa na Grécia como discurso racional sobre o divino e se desdobra numa reflexão específica da filosofia helenista no encontro com as tradições estoica, hebraica e cristã. Política como doutrina do poder encontramos em cada povo, mas de modos muito diferentes. Ela é entendida como organização da comunidade mediante um discurso refletido. Não só se faz política, mas também se pensa política. Em Aristóteles, "política" tem a ver com a organização comunitária, que é produto da política como doutrina ou reflexão. Já o conceito "teologia política" passou por um longo processo histórico que o autor analisa e discute ao longo de todo o livro. Em sentido próprio, o conceito deve ser definido como "discurso da razão em torno do viver em comum" das pessoas $^{3}$ e diz respeito à convivência em sociedade/comunidade. Importante na pesquisa é trabalhar com uma racionalidade aberta ao se refletir sobre a origem e fundamento do

\footnotetext{
1 O artigo foi recebido em 10 de maio de 2018 e aprovado em 06 de setembro de 2018 com base nas avaliações dos pareceristas ad hoc.

2 Doutor em Teologia pela Faculdades EST. Professor de Missiologia e Teologia Prática. Contato: rezwetsch@gmail.com

3 SCATTOLA, M. Teologia politica. Lisboa: Ed. 70, 2009. p. 14.
} 
conceito. $\mathrm{O}$ autor entende tal origem não como no espaço e no tempo, mas como "condição de possibilidade" que permite retomar o conceito a cada vez, e criticamente 4 . Isto é, "teologia política" para ele é "filosofia política". Será só isso?

Em termos gerais, é possível resumir o argumento da obra seguindo de perto o cap. 5, que tematiza o século XX e no qual o autor resume os achados de sua pesquisa. Para Scattola, esse século reabriu o problema teológico-político ${ }^{5}$. O século XX reconstrói e interpreta a história da teologia política dos séculos anteriores e é especialmente importante considerar - para a teologia cristã - o que significa teologia política após "Auschwitz" (a matança científica dos judeus por decisão de Hitler). Nesse sentido, só no século XX é que se formulou um conceito de teologia política em sentido próprio, isto é, de um modo reflexivo e consciente de si próprio (entram aí as teorias da secularização, da emancipação humana em relação à teologia, e do exercício da liberdade de pensamento).

O autor apresenta as teorias de Max Weber (secularização das ideias religiosas, desencantamento do mundo, sociologia compreensiva, ética protestante e capitalismo - 1904/5 e 1920) e de Hans Kelsen, o qual já em 1913 identificou Deus e o Estado, Criador e criação na relação entre Estado e direito. Ele atribui transcendência ao Estado, visto como absoluto (assim se colocando no lugar de Deus). Para ele, a teologia se conserva na política por um translado do sagrado ao secular. Essas ideias se tornam mais radicais em Carl Schmitt", para quem "todos os conceitos mais fecundos da moderna doutrina do Estado são conceitos teológicos secularizados"7. Para esse e outros autores contrarrevolucionários, o liberalismo e o Estado de direito são desvios condenáveis, pois a "essência da teologia e da política" se dá no "decisionismo e na ditadura, as duas formas políticas e jurídicas em que se exprime o absolutismo da soberania"8. Não por acaso este autor estudou a pessoa de Cristo e acabou por defender a ideia do Führer, que se encarnou depois em Adolf Hitler! Passando pela Reforma, Hobbes, Nietzche, Schmidt chega à conclusão de que a afirmação do Novo Testamento "Jesus é o Senhor" significa que a mediação da igreja já não é possível, e que em seu lugar só é concebível agora "uma única forma de representação da transcendência, a realizada pelo deus mortal na total imanência do Estado" ". Algo a ver com o que anda acontecendo no mundo atual em relação ao "império dos nossos dias" ou ao "mercado absoluto"10?

Nesse sentido, obra recente de Giorgio Agamben é importante para definir o que vem a ser, nos termos dos debates atuais sobre a teoria política, o "estado de exceção", que tem em Carl Schmitt um de seus formuladores clássicos. Para Agamben, já

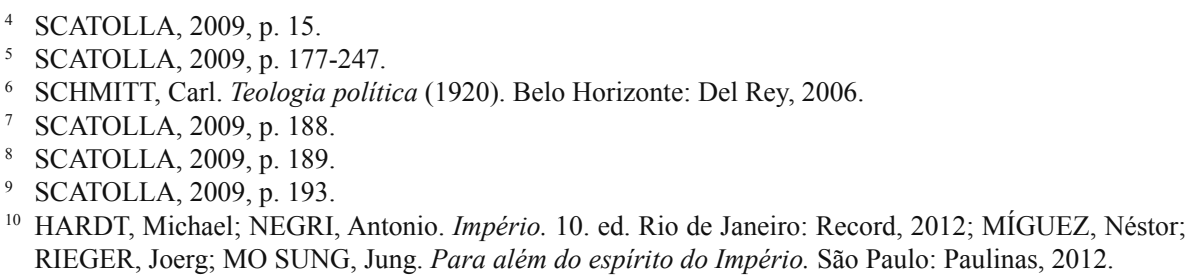


vivemos nesse tipo de estado, uma vez que o estado atual "se apresenta como a forma legal do que não pode ter forma legal"'11.

Ao analisar as perspectivas do século XX, Scattola destaca as ideias de pensadores judeus como Walter Benjamin e Jacob Taubes, e sua reinterpretação do messianismo político e da escatologia política como um confronto praticamente sem solução racional entre imanência e transcendência na história e a dificuldade de se posicionar diante dos usos do poder político na história humana. ${ }^{12}$ Ele apresenta as seguintes teses: 1) a política foi corrompida pela teologia: isto é, temos uma degeneração do sagrado e a construção niilista do Estado (L. Strauss, E. Voegelin. R. Guardini, K. Löwith) ${ }^{13}$; 2) a política salva pela teologia, defendendo uma "teologia da história" (W. Benjamin, J. Taubes) ${ }^{14} ; 3$ ) a alternativa política à teologia - secularização (E. Topisch, H. Blumenberg, J. Assmann $)^{15}$; 4) a alternativa teológica à política - êxodo e reserva escatológica (F. Gogarten (luterano), E. Peterson (católico), H. Blumenberg e a Teologia Política II (resposta a C. Schmitt)) ${ }^{16}$.

Por fim, Scattola apresenta o debate atual em dois extensos tópicos:

1) A nova teologia política, que corresponde aos anos de 1960/70, especialmente com os trabalhos de Johann Baptist Metz (católico) e Jürgen Moltmann (reformado), nos quais encontramos atenção cuidadosa em relação à questão social e à emancipação dos oprimidos não só como necessidade histórica, mas como necessária de um desenvolvimento dogmático ${ }^{17}$ p. 233. A questão é enfrentar a relação complexa entre fé e mundo para livrar a mensagem evangélica do aspecto privatista em que foi encerrada e formular a promessa escatológica (reino de Deus) "sem perder de vista as condições de nossa sociedade" ${ }^{18}$. A teologia política será assim um aspecto fundamental da construção da consciência crítica da sociedade atual, isto é, o "caráter fundamental da fé é a promessa escatológica, que olha para o Reino de Deus como para a plenitude que virá interromper o tempo da terra. $\mathrm{O}$ futuro, e não o presente ou o passado, é por isso o critério da verdade [...] e é sobre a promessa do reino que há de vir que se devem avaliar todas as sociedades humanas"19. Isso resume o pensamento de Metz. Quanto a Moltmann, o foco está na hermenêutica da $c r u z^{20}$, sobre a qual Scattola assim se manifesta: "A cruz [...] implica uma separação radical, que liberta o cristão da subjugação ao mundo, da necessidade de encontrar confirmações e de construir ídolos humanos para superar a angústia na soberba"21. A libertação dos ídolos abre as pessoas do povo de Deus (crentes) a uma comunidade universal com

\footnotetext{
11 AGAMBEN, Giorgio. Estado de exceção. São Paulo: Boitempo, 2004. p. 12.

12 SCATOLLA, 2009, p. 194ss.

13 SCATOLLA, 2009, p. 196-212.

14 SCATOLLA, 2009, p. 212-216.

15 SCATOLLA, 2009, p. 216-223.

${ }_{16}$ SCATOLLA, 2009, p. 223-232.

17 SCATOLLA, 2009, p. 233.

18 SCATOLLA, 2009, p. 235.

19 SCATOLLA, 2009, p. 235.

${ }^{20}$ MOLTMANN, Jürgen. O Deus crucificado. Santo André: Academia Cristã, 2014.

${ }^{21}$ SCATOLLA, 2009, p. 238.
} 
todos os "outros". A partir da cruz, os "outros" são as vítimas da soberba e do medo de que se alimenta o fetichismo das religiões políticas. Os "outros" são os frágeis e os pobres nas sociedades dos ricos e fortes. "A liberdade da fé cristã, conquistada e oferecida pela cruz, transforma [...] a autoafirmação ímpia de um povo na solidariedade com as suas vítimas e numa prática que as representa a todas"22. Os dois termos dessa "nova teologia política" mais importantes são escatologia e liberdade, centrais para as discussões nos dias de hoje.

2) A teologia nos dias de hoje. O autor aponta resumidamente para as teologias da libertação que emergiram a partir dos anos de 1970: teologia da libertação, teologia negra (EUA, África), teologia feminista (e suas variações), teologia minjung (Coreia), teologia da paz. Em comum, essas teologias destacam a teologia como ciência crítica, que questiona todas as formas de poder usurpador das liberdades políticas, democráticas. Seu ponto de partida é a encarnação de Deus em Jesus de Nazaré. É essa abordagem cristológica que lhe permite afirmar: a prática das pessoas crentes não rejeita o mundo (secularizado) para se isolar na divindade nem se reduz à ação no mundo e para o mundo (pura imanência). Antes aponta para a "busca do divino" através do ser humano (talvez se possa dizer, sob a inspiração de Mateus 25.31 ss ${ }^{23}$ ). Daí nascem a opção pelos pobres, inspirada na prática de Jesus, e a luta das pessoas cristãs pelos deserdados da terra (e hoje pela própria Terra, isto é, a ecoteologia). As teologias feminista, womanist, mujerista, ecofeminista, como, por exemplo, nos escritos de Ivone Gebara $^{24}$, radicalizam aquelas afirmações desdobrando para um espectro mais amplo o conceito de "libertação", na linha aberta por J. L. Segundo da libertação da teologia como prática e como conhecimento. O destaque final do autor é para Dorothee Sölle ${ }^{25}$, teóloga luterana marginalizada na academia alemã, mas cuja teologia e prática inspiraram muita gente nos EUA, na América Central e na América Latina. Sölle esteve várias vezes nessas regiões estabelecendo um diálogo frutífero com a teologia da libertação e as teologias feministas latino-americanas. No embate com a teologia de C. Schmitt, Sölle faz uma crítica radical à distinção entre política e teologia e afirma ser necessário aceitar o fato paradoxal de que "a política é imediatamente teologia e que, vice-versa, a teologia é sempre e só política" ${ }^{26}$. Para Sölle, a teologia que não se torna contribuição à "práxis justa" ou "ortopráxis" não conduz a uma "vida autêntica", não mais entendida como vida individual burguesa, mas como existência social histórica que nos insere numa caminhada comunitária que desafia para uma consciência social crescente e libertadora. O evangelho para ela não é um conjunto de princípios e regras, mas antes um exemplo de crítica e transformação a partir do testemunho histórico de Jesus de Nazaré. Na vertente mais escatológica, hoje se está resgatando o messianis-

22 SCATOLLA, 2009, p. 238.

23 ALTMANN, Walter. Lutero e libertação. 2. ed. rev. e ampliada. São Leopoldo: Sinodal; EST, 2016. p. 345-358.

${ }^{24}$ GEBARA, Ivone. Teologia ecofeminista. Ensaio para repensar o conhecimento e a religião. São Paulo: Olho d'Água, 1997.

25 SCATTOLA, 2009, p. 243ss.

${ }_{26}$ Apud SCATTOLA, 2009, p. 245. 
mo defendido por Benjamin e a doutrina do apóstolo Paulo, com bons representantes da filosofia e teologia italianas (G. Agamben, A. Rizzi, R. Panattoni). ${ }^{27}$

$\mathrm{O}$ autor apresenta, portanto, um panorama bastante completo da história do conceito teologia política, mas, ao final, se esperaria mais dessa exaustiva pesquisa. É que o autor simplesmente arrola autores e revistas atuais que levam adiante a discussão em torno da teologia política, mas gera certa frustração no leitor ou leitora, especialmente depois de retomar as afirmações da "nova teologia política" ou as teses das teologias da libertação. O debate não pode ficar nas academias, mas deve baixar para a vida concreta, onde as vítimas do sistema dominante não podem mais esperar por soluções das aporias teóricas. Antes, necessitam contar com mãos estendidas, mentes abertas ao diálogo e compromisso pessoal e comunitário com a luta pela defesa da vida, hoje sumamente ameaçada em todos os lugares do mundo. Não se trata de desprezar o debate teórico. Pelo contrário, trata-se de levá-lo ao confronto com as realidades cambiantes deste mundo dominado atualmente por um só sistema econômico, político e midiático. Parece que o autor não leva em conta as comunidades de base, os movimentos sociais transformadores, o engajamento de milhares de pessoas em projetos alternativos que questionam a sociedade dominante atual, inspirados nessas teologias e visões de mundo, mesmo em filosofias da história que se insurgem contra o "absolutismo" do sistema de mercado (penso em G. Agamben, G. Vattimo, A. Badiou, S. Zizek). É um bom livro, mas inconcluso, falho ao tentar manter certa "neutralidade" típica da academia europeia.

\section{Referências}

AGAMBEN, Giorgio. Estado de exceção. Trad. Iraci D. Poleti. São Paulo: Boitempo, 2004. ALTMANN, Walter. Lutero e libertação. Releitura de Lutero em perspectiva latino-americana. 2. ed. rev. e ampliada. São Leopoldo: Sinodal; EST, 2016.

GEBARA, Ivone. Teologia ecofeminista. Ensaio para repensar o conhecimento e a religião. São Paulo: Olho d'Água, 1997.

HARDT, Michael; NEGRI, Antonio. Império. Trad. Berilo Vargas. 10. ed. Rio de Janeiro: Record, 2012.

MÍGUEZ, Néstor; RIEGER, Joerg; MO SUNG, Jung. Para além do espírito do Império. São Paulo: Paulinas, 2012.

MOLTMANN, Jürgen. O Deus crucificado. Trad. Juliano B. de Melo. Santo André: Academia Cristã, 2014.

SCHMITT, Carl. Teologia politica (1920). Trad. Elisete Antoniuk. Belo Horizonte: Del Rey, 2006.

27 SCATTOLA, 2009, p. 246s. 